\title{
РИФТОГЕНЕЗ В ОСАДОЧНЫХ БАССЕЙНАХ РОССИЙСКОЙ АРКТИКИ
}

Бурлин Ю.К., Спупакова А.В. (геол. $\phi-m M \Gamma Y$ )

There are two main blocks within Russian Arctic, which formed on the base of continental type of the Earth crust and reworked several times during the rifting stages. Basins in the Barents-Kara shelf had been determined the Paleozoic riftogenesis. The Novaya Zemlya folding belt overcover the east ending of rift zone. The Eastern block comprises the eastern part of Laptev sea, East Siberian and Chuckchi seas. The big extending rift zone is the reason of the sedimentary basins formation here. They are associated mainly with rifting of the Jurassic-Early Cretaceous time and have very big sediments thickness.

Рифтогенез, раскрытие океанических котловин и др.) привели к формированию современной суперструктуры этого региона. Здесь целесообразно выделять. Норвежско-Баренщево-Карский и Восточно-Сибирско-Чукотский блоки. Фундамент блоков докембрийский, в некоторых участках в строении основания осадочных бассейнов принимают участие байкалиды и каледониды. Разрезы бассейнов сложены мощныпи толщами терригенных и карбонатньх пород палеозойских и мезозойских отложений. В наибольшей степени эти процессы, в т.ч. генерация углеводородов, происходят в зонах развития рифтогенеза в связи с глубоким прогревом. Рифтогенные структуры располагаются под наиболее глубоко прогнутыми участками бассейнов, над ними часто расположены крупные инверсионные поднятия. В подобной ситуация находится групша бассейнов в районе Финнмаркен в южной части Баренцева моря (Тромсе, Хаммерфест и Нодкап). Все они расположены в зоне влияния рифтогенеза, который происходил в интервале времени от среднего карбона до начала триаса. Определённую фазу герцинского тектогенеза отражает трансгрессивное перекрытие пермскими отложениями нижележащих. Предтриасовый размыв.имел большое значение. Особенно выделяется триасовое время глубокого компенсированного прогибания, наследующего рифтогенные прогибы в наиболее прогнутых участках Баренцева моря, где палеозойские породы были погружены на глубины более 7 км. Триасовые отложения формировались на склонах и образовывали глубоководные конусы выноса - фены. начало формирования Новоземельской складчатой мегаструктуры началось с конца триаса и продолжалось позже в юре в связи с общим сжатием, направленным с востока. Все осадочные толщи, отвечающие основным этапам развития, являются весьма нефтегазоперспективными. Палеозойские отложения, кроме известных районов Тимано-Печорского бассейна и прилегающего шельфа Печёрского моря, где в них заключены многочисленные залежи, достижимы в Центральнобаренцевской зоне поднятий (свод Федынского, поднятия грамберга и Маловищкого и др.), в Приновоземельской области (Адмиралтейско-Пахтусовская зона). Интерес представляют и в северо- восточные районы Карского моря, где глубины залегания палеозоя значительно меньше, чем в областях глубо- кого прогибания Баренцева моря. на запад. Этот сравнительно молодой структурный план наложен на более древние тектонические элементы другой ориентировки. В пределах восточного арктического блока разрез осадочньх бассейнов начинается со среднедевонских отложений, залегающих на более древнем дислоцированном франклинском комплексе. Простирание прогибов, выполненнњгх досреднеюрскими членами разреза имеет субмеридиональную ориентацию. Рифтогенез, начавшийся в средней юре привел к образованию прогибов и осадодных бассейнов субширотной ориентировки. Нанболее крупным является Северо-Чукотского прогиб, выполненный толщей осадочных пород нижнеговерхнего мела и кайнозоя (брукинский комплекс) мощностъю не менее 16 км. На сейсмических профилях в западной части шельфа Чукотского моря запечатлены, по крайней мере, три геологических события. В нижней части осадочного чехла прогиба наиболее ярко проявлено нижнемеловое стратиграфическое и угловое несогласие. Это несогласие является границей двух основных частей разреза. Залегающая ниже несогласия толща может являться рифтовым комплексом, ниже которого залегаю слои элсмира Последние. на сейсмических разрезах характеризуются хорошо выраженғыми отражениями. Вышележащий рифтовый комплекс юрского возраста перекрывается нижней, меловой по возрасту, частью брукского комплекса, сложенной территенным отложениями, нарушенными разломами. Верхнебрукский комплекс, залегающий после перерыва, относится по возрасту к кайнозою. На основе обобщения материалов, можно сделать вывод, что севернее о. Врангеля располагается Северо-Чукотский надрифтовый возможный нефтегазоносный бассейн как самостоятельный достаточно крупный объект, характеризуюшийся очень большой мощностью отложений предположительно в основном мелового возраста. В ограничивающих бассейн приподнятых зонах к поверхности приближены и более древние отложения. Все части разреза являются высокоперспективными. 